\title{
Information Technology for Educational Management at a Ugandan Public University
}

\author{
Ronald Bisaso \\ Department of Management Studies, University of Tampere, Finland
}

\begin{abstract}
This article discusses the introduction of information and communication technology in educational management (ITEM) into the academic and financial administrative activities of Uganda's oldest and largest university. This university has seen the relevance of ITEM especially in enhancing its efficiency and effectiveness in view of increased enrolment. Data used were collected through documentary analysis and thematic interviews. The interviews involved 17 respondents comprising two top managers, eleven deans and directors of faculties, schools or institutes and four administrative personnel knowledgeable about the academic and financial ITEM systems. Data were transcribed and emergent themes identified. The findings illuminate a mixture of optimistic expectations and lamentations to the ITEM systems that have been aimed at integrating the highly decentralized administrative structure in the university. These comprehensive ITEM systems have been a vendor-developed and donor-funded venture. Consequently, adopting the systems has in some instances been compounded by incompatibility to the existing administrative practices. In light of these findings, it is suggested that ITEM systems ought to be first piloted in a few units prior to university-wide deployment in this developing setting with its peculiarities. Besides, on-site ITEM development would more likely remedy the mismatch between ITEM systems and the administrative processes it is meant to support even though they are projects and time-bound.
\end{abstract}

Keywords: Information technology in educational management (ITEM), information systems, management, university

\section{INTRODUCTION}

Universities as organizations are increasingly embracing information communication technology in educational management (ITEM) for their managerial accuracy, efficiency and effectiveness. This is premised on the changing requirements for more accountability since universities have become responsible to a variety of stakeholders for instance; students,

Please use the following format when citing this chapter:

Bisaso, R., 2009, in IFIP International Federation for Information Processing, Volume 292; Evolution of Information Technology in Educational Management; Eds. Tatnall, A., Visscher, A., Finegan, A., O’Mahony, C., (Boston: Springer), pp. 83-94. 
governments, the private sector, funding bodies, and standards agencies. Yet, at the same time, universities are just actors in the environments in which they operate, influencing and being influenced by other actors (Amaral, Jones, \& Karseth, 2002 p. 281; Maassen \& van Vught, 2002 p. $225)$. So, the usually timely and errorless information that computerization can provide is an essential aspect for the universities' systemic and systematic responsiveness. Moreover, '[university] organizations with an inferior [information technology] IT infrastructure will be at a competitive disadvantage and will find it difficult to stay in business' (McCredie, $2003 \mathrm{p}$. 22).

Research on ITEM in universities has been reported for example; case studies on ITEM usage in workload planning in the United Kingdom (Burgess, 1996) and in Finland (Hölttä \& Karjalainen, 1997), and students' admission in the United States (McClea \& Yen, 2005). Besides, anecdotal evidence reveals some studies on ITEM in universities in the developing regions e.g. Rodrigues \& Govinda (2003) highlight advantages accruing from onsite ITEM development at a university in Mauritius. In addition, previous findings from Ugandan universities show that initial automation has been ad hoc (Magara, 1999), with low computer use among deans, heads of department and secretaries who manage students' information (see also Wakanyasi, 2002; Zziwa, 2001). Also, Inyaga (2002) reveals that there is more information technology usage in students' records management compared to research and library functions. A recent study has further proposed a strategy for an information management system for Uganda's higher education sector (Magara, 2006).

Even then, research on ITEM utilization in universities has remained generally scanty with few case studies (Tatnall \& Davey, 2005 p.212), practitioner-oriented and theoretically deficient (Allen, Kern, \& Mattison, 2002 p.160). Additionally, little attention has been paid to the dynamics of the higher education environment in Uganda and its linkages to the intensifying utilization of ITEM in universities hence this paper. Whether a vendor-evolved ITEM system fits into the prevailing financial and academic administrative circumstances at a developing country premier institution is another intention of this paper. The rest of this paper is structured as follows. First, the subsections on the changing context of institutional management and the evolution of ITEM at Makerere University are presented. The research question and the conceptual framework follow. The method used is given followed by the findings, and finally, the discussion and conclusions.

\subsection{The Changing Context of Institutional Management at Makerere University}

Makerere University was established in 1922 and is the largest university comprising 22 academic units including; eleven faculties, five schools and six institutes. The total student enrolment was 33,488 as at July 2007 (Makerere University, 2007). Makerere University has both centralized and 
decentralized management. There are a number of hierarchical positions including; the vice chancellor as the executive head, with two deputies (one for academic affairs and the other for finance and administration), university secretary, university bursar, academic registrar among others, all comprising top management. The deans or directors of schools or faculties or institutes are the middle managers responsible for academic, administrative and financial matters in their faculties, schools or institutes whereas the heads of departments are in-charge of academic matters at the lowest academic unit.

Institutional leadership is supported by management bodies like the university council - the highest decision-making organ, and senate responsible for all academic affairs of the university. Furthermore, the university also operates a committee structure at faculty level such as faculty boards, research and higher degrees committees, faculty finance committees, and the new faculty quality assurance committees all aimed at collective decision-making. The coordination of academic and financial activities is the responsibility of the academic registrar and university bursar respectively. The bursar authorizes all payments made by any unit of the university while the academic registrar ensures the authenticity of academic enrolment, progression and graduation. Following administrative decentralization, each faculty has either a deputy registrar and one faculty registrar or at least a faculty registrar depending on its size. These personnel are responsible for academic coordination at faculty level on behalf of the central academic registrar's department. Similarly, each faculty or school or institute has an accountant responsible for the financial procedures and transactions at that level on behalf of the bursar's office or finance department.

The present nature of management at Makerere University has been a result of recent changes in Uganda's higher education sector, a consequence of public sector reforms. These reforms have culminated into new legislation, decline in funding from government amidst increasing demand for higher education, and hence the entry of market approaches in public universities. For instance in 1992 private higher education became government policy marking the beginning of private sponsorship or fee paying programs (Court, 1999; Mayanja, 2001) with students enrolling on either day or evening programs. There was also semesterization of all academic provisions (Court, 1999; Mayanja, 2001; Musisi \& Muwanga, 2003). Because faculties, schools, institutes and departments had been asked to become entrepreneurial - designing courses that the market would be willing to pay for, student enrolments have increased from 7000 students in the academic year 1993/1994 (Musisi \& Muwanga, 2003 p. 33) to 33,488 students as at July 2007 (Makerere University, 2007).

These increasing enrolments coupled with diversity in funding alternatives especially private sponsorship, have seen the devolution of the financial (Mamdani, 2007 p. 175), academic and administrative structures (Court, 1999; Epelu-Opio, 2002). However, this extensive devolution has not only made financial management complex but has also put to question 
the allocation and monitoring of the academic and financial resources (see also Visitation Committee to Public Universities 2006, 2007). Yet with the prevailing private sector practices, Ugandan public universities ought to step up their accuracy, efficiency and effectiveness. Hence, Makerere University has started strengthening its administrative operations through ITEM systems utilization for management reporting and basic evidence-based planning and decision-making.

\subsection{Evolution of ITEM at Makerere University}

While computers were introduced in Uganda in 1967, adoption has been at snail-pace (Mulira, 1995). It was not until the early 1980s that systematic introduction of information and communication technology (ICT) in Makerere University commenced with funding from the African Development Bank (ADB), as an initiative of an individual university professor (Tusubira, 2005 p.89). In 1991, the university introduced e-mail usage with support from the International Development Research Council (IDRC). This project was short-lived especially with departure of an individual change agent who managed the network (Musisi \& Muwanga, 2003 p.28). Over the years various units have made efforts to continue operating in a 'connected' environment e.g. in 1998 the faculty of law embarked on the use of ICT in teaching, research and administration by hiring a consultant, and with support from United States Agency for International Development (USAID), a legal information centre was established. In 1999, the newly established faculty of forestry was also fully networked with funding from the Norwegian Development Agency (NORAD). The faculty of technology has also been furnished with large functional computer laboratories (Musisi \& Muwanga, 2003 p.28).

Attempts at university-wide ICT initiatives have been reported to start in 1999 after envisioning ICT as integral component in rebuilding the university (Makerere University, 2000 p. 12-13). This has provided a basis for the evolution of an ICT Policy and Master Plan, with the vice chancellor as chair of the ICT implementation committee. In the same way, the Directorate of ICT Support (DICTS), a service unit under the vice chancellor's office has been established (Musisi \& Muwanga, 2003 p.29). The university has become a networked campus with total connectivity and access to electronic research journals has been facilitated through Makerere Library Information System (MakLIBIS). These initiatives have been extensively funded by the Swedish International Development Cooperation Agency (SIDA) (see Greenberg \& Versluis, 2005). It should be noted that the urgency of a Financial Information System (FINIS), Academic Records Information System (ARIS) and the Human Resource Information System (HURIS) to augment the administrative processes has been addressed through funding from NORAD. Whereas the anticipated 'formal commissioning' and full production had been scheduled for May 12, 2005 (Greenberg \& Versluis, 2005 p.20), it was not until January 12, 2007 that the 
FINIS, ARIS, and HURIS systems were commissioned (Luboobi, 2007 p.5). It is argued that the plans for implementation of these systems have been rather unrealistic hence the delays in complete utilization. For example, 'the need to customize the systems [has] not [been] fully understood or analyzed, and this has caused some additional delay' (Greenberg \& Versluis, 2005 p.20). However, in the opinion of Greenberg and Versluis, the project has been quite on time if based on a realistic timeline, and the anticipation that the ITEM systems would be in production in the 'foreseeable future, and should meet expectations'.

\section{RESEARCH QUESTION AND CONCEPTUAL FRAMEWORK}

The following research question and research framework guided this study.

What is the current nature of academic and financial information systems utilization in the changing context of institutional management at Makerere University?

Universities as open systems are in a perpetual state of instability. Whereas universities affect and are affected by their environments, the interaction is as unpredictable as it is nonlinear eliciting equally indeterminable consequences (Birnbaum, 1988 p. 34-35). This is further compounded by the highly fragmented nature of universities according to disciplines (Clark, 1983), yet universities also have several hierarchical levels (Hölttä, 1995 p. 235). Within this complexity, universities have opted for various tools to maintain equilibrium in their subsystems for instance departments and faculties as they operate in or respond to their increasingly unstable internal and external environments. The tools have been either 'soft' taking the form of sanctions of committees in the decentralized management structures or 'hard' tools - in the form of computerized management information systems. Hierarchical management of complex subunits can solve the information problem (Hölttä \& Karjalainen, 1997 p. 231; McClea \& Yen, 2005 p. 89-91) due to the reduced amount of information on each particular unit. The higher hierarchical level then monitors output and regulates input through 'feedback information on output variables, without any need to understand the internal mechanisms of the [decentralized] subsystems' (Hölttä \& Karjalainen, 1997 p.231). This would then keep the university and its units in relative equilibrium as it can stabilize or accelerate its operations basing on the prevailing environmental conditions. 


\section{METHODS AND DATA ANALYSIS}

This study is an exploratory case study investigating the utilization of academic and financial information systems in a changing context of institution management at Makerere University. Data were collected from 17 respondents through face to face thematic interviews on the relevance and the nature of academic and financial information systems utilization in this context. The study explored each of these participant's opinions on this guiding theme. The respondents included; the deputy vice chancellor - in charge of finance and administration and the academic registrar who represented the opinions of top university management with respect to financial monitoring and academic coordination. The director of the graduate school was included in the study on ground of being a coordinator of graduate research in the university. The deans and directors participating in the study were representative of Makerere University's 22 academic units consisting of 11 faculties, five schools and six institutes (Makerere University, 2007).

Using stratified sampling, nine deans and one director were selected from the physical sciences (computing and information technology, technology, library and information sciences, science), biological sciences (veterinary medicine, agriculture and medicine) and the social sciences (social sciences, law and education). Stratification was preferred because the sample drawn reflected the proportions of individuals with certain characteristics of the population (Creswell, 2003). In addition, the researcher sought the opinions of four administrative personnel courtesy of the deputy vice chancellor and the academic registrar as they regarded them practically knowledgeable about the ITEM systems. The researcher also purposively selected the accountant at the school of education basing on the respondent's knowledge of actual utilization of the finance information system. All interviews were recorded. Transcriptions were made according to the respondents' opinions and emergent themes were identified from the data as they provided inroads to answering the research question.

\section{FINDINGS}

The data from this study suggests that the top university managers, deans or directors and administrative personnel participating in the study have seen the relevance of the ITEM systems in the efficient and effective operation of the university. The general picture of the utilization is diverse and fragmented in the case of the academic records system (ARIS). On the other hand, the finance information system (FINIS) is relatively homogeneous and consolidated. These ITEM systems are part of an integrated system procured from a vendor through donor support and installed in the first half of this decade. The system runs on a relational database and operates on a network. The procured integrated system comprises ARIS, FINIS, HURIS and 
MakLIBIS. The discussion in this paper concentrates on ARIS and FINIS because these are supposedly the most widely used systems in academic units and at all administrative levels in the academic and financial operations of the university. The urgency of ARIS and FINIS is premised on the opportunity for centralized coordination of the highly decentralized nature of the university. In the same way, the increased enrolment and the devolution of financial and academic responsibilities renders manual operations ineffective and inefficient hence the need for ITEM systems.

While the university has opted for a comprehensive system that would bring together all the academic units, the incompatibilities of the system with the administrative practices has impeded complete utilization. Besides, faculties have either opted for supplementary systems or used generic software packages for their administrative support especially in students' examination results management. The interviews have further revealed that even at the centre - the academic registrar's department who are the custodians of ARIS, customization of this vendor-evolved ITEM system has been elusive hence the evolution of a supplementary system - the 'results system'. It thus appears that the centre and faculties have both found the vendor-evolved ARIS incompatible to all the university academic administrative processes hence improvisation. Moreover, the ITEM system cannot meet certain peculiar requirements of the university's school of graduate studies for instance; there is completely a mismatch between ARIS and the administration of graduate programs and tracking of graduate students' progress. As a remedy, the graduate school has opted for a home grown system from the faculty of computing and information technology at this case university.

The actual process of using ARIS starts when undergraduate students manually fill in forms and these are handed over to the deputy registrar or faculty registrar. Depending on the skill level of the registrar and the secretaries at a given faculty, the student data is either entered into the system at the faculty or the filled-in hard copies are carried to the academic registrar's department at centre where student data is then captured. It is evident that even with the decentralized administrative personnel from the academic registrar's department; the advantages that would accrue from ARIS in decentralized arrangements are yet to be fully exploited. Some modules in ARIS such as time-tabling and other managerial components are not yet used. Although the ITEM system would be presumably aimed at reducing information at the centre, the current nature of utilization serves to pile information at the centre that this may blur its performance monitoring and evaluation role.

Nevertheless, the apparent interface between ARIS and FINIS is likely to enhance concerted utilization at the faculty level. For instance, after a student has paid tuition fees, the FINIS will reflect the credit on the 
university account but this money cannot be disbursed to any faculty ${ }^{5}$. It is not until a student has been registered in ARIS, and the bank slip number obtained on payment recorded, that the system would now recognize the identity of the payee and what is due to their faculty. On that basis, the utilization of ARIS could be relatively enhanced otherwise the faculty would not receive its percentage of the tuition hence curtailing its operations.

As already noted, the FINIS has been widely adopted. This is partly because it supports the distribution of income accruing from privately sponsored academic programs to faculties basing on the existing sharing ratios. Additionally, success in the utilization of FINIS has been partly due to the technical, financial and managerial support from the University of Bergen, Norway. The now more extensive utilization of FINIS has enabled the university to avoid being defrauded through inept manual verification processes at a time of increased students' numbers. A respondent from the finance department noted thus:

'... I will tell you, there are certain functions we had failed to do in finance. For example, it was never possible to find out how much a student had paid and what the balance is. It would take us to call a student and say bring your receipts and the student brings their receipts we add them up, we say now you were supposed to pay this, you have paid this [and] the balance is this, looking at the receipts from students. And the students used to forge right, left and centre. I am very sure that very many students studied without paying any tuition!'

The consequences of liability in case of financial errors possibly explain why the university has found it critical to solicit external support so that FINIS is fully utilized. Apparently, the university bursar can also issue monthly financial statements on the exact revenue and even the likely disbursements to the respective faculties because of the interface between FINIS and electronic bank statements from the respective banks on one hand, and FINIS and ARIS on the other.

However, the extent of FINIS utilization to disburse funds to faculties is still not as automatic as it ought to be. After the computations have been made as to what is due to which faculty or unit, cheques are then written to the respective faculties or units. This is because of the unsystematic flows of revenues from government for the payment of staff salaries, students' welfare, utilities like water, electricity, telephone bills etc. Hence there can be inadequacy of funds that if the central university administration is not keen, it may possibly transfer the figures when the money is actually not available. This finding shows that there is a mixture of 'soft' and 'hard' tools as the university maintains equilibrium. A faculty would not fully get what the central administration owes it but rather the bursar may make adjustments depending on the prevailing fiscal circumstances or requirements.

The central administration and the academic unit at which a privately sponsored student is registered have sharing ratios or percentages of the tuition fees paid by the student. 


\section{DISCUSSION AND CONCLUSIONS}

The study set out to investigate the question: what is the current nature of academic and financial information systems utilization in the changing context of institutional management at Makerere University?

Like in earlier studies on the evolution of ITEM in schools (Nolan, Brown, \& Graves, 2001; Wild \& Walker, 2001), prior attempts at Makerere University were individual efforts of a university professor. This may possibly explain why documented efforts at ITEM utilization spanning close to three decades have been slow and are yet to be entrenched at Makerere University even though the findings show that the relevance of ITEM is underscored by all the university personnel participating in this study.

Equally important is that universities are by nature decentralized according to disciplinary bounds but also integrated by institutional management through various means. In the case of Makerere University, faculties as subunits have become power centres perhaps even justifying their decisions to evolve or procure supplementary systems to become more responsive. The current university-wide ARIS and FINIS was centrally conceived as can be seen in the ICT Policy and Master Plan, the implementation committee under the chair of the vice chancellor, DICTS - a centralized service unit under the vice chancellor's office etc. It is noticeable that this approach to the infusion of ICT into the university administrative process has been rather incongruent to the prevailing dynamics of shifts in academic, administrative and financial decentralized responsibility. Earlier ITEM ventures at Makerere University have transitioned from individual to specific faculty initiatives (Musisi \& Muwanga, 2003 p.28) yet this university-wide initiative has been somewhat centralized even after the introduction of decentralization reforms. Within this changing context of institutional management, it is argued that possibly piloting ARIS and FINIS at faculty level to full utilization would have created ownership of the venture among the pilot faculties and that the other faculties would have systematically followed.

Besides, it has also been noted that instead of the centre concentrating on only 'reduced' information from faculties for performance monitoring and evaluation, it is overwhelmed with bulks of information from the decentralized academic units. This is at variance with what Hölttä \& Karjalainen (1997 p.231) have expressed and may have a negative effect on the institutional monitoring mechanisms. This prevailing condition could be a result of time-bound ITEM projects that are misaligned to the dynamics of institutional management. An alternative to the ITEM systems in facilitating institutional integration has been the softer mechanisms of committee structures and minutes from meetings against which academic and financial decisions have in most cases been made.

As an open system (see Birnbaum, 1988), Makerere University has seen the implementation of its ITEM systems affected by the environment from 
which it has been initiated and supported. In this same vein, it is clear that ITEM systems at Makerere University have had a history of donor-funding (Greenberg \& Versluis, 2005 p.20; Musisi \& Muwanga, 2003 p.28; Tusubira, 2005 p.89). Whereas this is an indicator of successful institutional partnerships, the timelines at times associated with these projects may not permit assimilation and even the preparedness of the university to carry on the ventures is often curtailed by the availability of finances. This has also had its effect on cultivating a sense of ownership that only surfaces when projects are fazing out, for example, the recently introduced technology fee as part of the students' tuition fees. Against this backdrop, vendor-evolved products have been the option since they would not presumably require a lot of time in proffering requirements analyses hence suiting the donor's project timelines. Moreover the vendor products have adequate documentation for reference in case of technical difficulty (Gorr \& Hossler, 2006 p.14). On the other hand, legacy or homegrown systems have been found inseparable from the institutions where the vendor products have been introduced because they are easily adjustable in case of a change in the processes it is meant to support (Gorr \& Hossler, 2006 p.18). This is similar to the findings in this study where a vendor product was installed but traditional or supplementary systems have been evolved in the different faculties and also the academic registrar's department. At the same time, Rodrigues \& Govinda (2003 p.46) highlight the benefits that an onsite ITEM system has provided for the University of Mauritius enabling the project to address the peculiar processes in the university. It is argued that the current mismatch in the utilization of ARIS and FINIS e.g. in the academic activities of the school of graduate studies would have been probably minimized or avoided through a similar approach.

\section{REFERENCES}

Allen, D., Kern, T., \& Mattison, D. (2002). Culture, power and politics in ICT outsourcing in higher education institutions. European Journal of Information Systems, 11, 159-173.

Amaral, A., Jones, G. A., \& Karseth, B. (2002). Governing higher education: Comparing national perspectives. In A. Amaral, G. A. Jones \& B. Karseth (Eds.), Governing higher education: National perspectives on institutional governance. (pp. 279-298). Dordrecht: Kluwer Academic Publishers.

Birnbaum, R. (1988). How colleges work. the cybernetics of academic organization and leadership. San Francisco: Jossey-Bass.

Burgess, T. G. (1996). Planning the academic's workload: Different approaches to allocating work to university academics. Higher Education, 32, 63-75.

Clark, B. R. (1983). The higher education system. academic organization in cross-national perspective. Los Angeles: University of California Press. 
Court, D. (1999). Financing higher education in Africa: Makerere, the quiet Revolution. Washington D.C.: The World Bank and The Rockefeller Foundation.

Creswell, J. W. (2003). Research design qualitative, quantitative and mixed methods approaches. London: Sage.

Epelu-Opio, J. (2002). Higher education reform at system and institutional level. the case of Makerere university. British Council International Seminar, Barnet Hill Conference Centre, London.

Gorr, W., \& Hossler, D. (2006). Why all the fuss about information systems? or information systems as golden anchors in higher education. New Directions for Higher Education, (136), 7-20.

Greenberg, A., \& Versluis, G. (2005). Sida supported ICT project at Makerere University in Uganda No. Sida Evaluation 05/17). Stockholm: Swedish International Development Cooperation Agency, Department for Research Cooperation.

Hölttä, S. (1995). Towards the self-regulative university. University of Joensuu. University of Joensuu Publication in Social Sciences, 23

Hölttä, S., \& Karjalainen, K. (1997). Cybernetic institutional management theory and practice: A system of flexible workload for university teachers. Tertiary Education and Management, 3(3), 229-236.

Inyaga, A. (2002). The utilisation of information and communication technology (ICT) in the management of Uganda Martyrs University, Nkozi. Unpublished Masters thesis, Makerere University.

Luboobi, L. S. (2007). Address by the vice chancellor on occasion of the 54th and 55th graduation ceremonies. Freedom Square, Makerere University:

Maassen, P. A. M., \& van Vught, F. A. (2002). Strategic planning. In I. Jenniskens (Ed.), Management and decision-making in higher education institutions (pp. 225-240). The Hague: Lemma Publishers.

Magara, E. (1999). Automation of students records system at Makerere University: An analytical approach. Unpublished Masters thesis, Makerere University.

Magara, E. (2006). A framework for an integrated student information management system for higher education in Uganda. Unpublished $\mathrm{PhD}$ dissertation, University of South Africa.

Makerere University. (2000). Makerere university strategic plan 2000/01 2004/05. Kampala-Uganda: Planning and Development Department Makerere University.

Makerere University. (2007). Makerere university. "we build for the future". Retrieved September, 28th, 2007, from http://mak.ac.ug/makerere/

Mamdani, M. (2007). Scholars in the marketplace. the dilemmas of neoliberal reform at Makerere University, 1989-2005. Kampala: Fountain Publishers Ltd. 
Mayanja, M. K. (2001). Makerere University and the private students scheme. International Higher Education, 25, 11-13.

McClea, M., \& Yen, D. C. (2005). A framework for the utilization of information technology in higher education admission department. International Journal of Educational Management, 19(2), 87-101.

McCredie, J. (2003). Does IT matter to higher education? Educause Review, , 15-22.

Mulira, N. K. (1995). Managing information technology in Uganda: Strategies and policy formulation. Information Technology for Development, 6, 95-105.

Musisi, N. B., \& Muwanga, N. K. (2003). Makerere university in transition, 1993-2000. Oxford and Kampala: James Currey and Fountain publishers.

Nolan, P. C. J., Brown, M. A., \& Graves, B. (2001). MUSAC in New Zealand from grass roots to system-wide in a decade. In A. J. Visscher, P. Wild \& A. C. W. Fung (Eds.), Information technology in educational management: Synthesis of experience, research and future perspectives on computer-assisted school information systems (pp. 55-75). Dordrecht: Kluwer.

Rodrigues, A. J., \& Govinda, S. (2003). Towards an integrated management information system: A case of the University of Mauritius. Information Technology for Development, 10, 41-56.

Tatnall, A., \& Davey, B. (2005). Future directions in ITEM research. In A. Tatnall, J. Osorio \& A. Visscher (Eds.), Information technology and educational management in the knowledge society (pp. 209-217). New York: Springer.

Tusubira, F. F. (2005). Supporting university ICT developments: The Makerere university experience. African Development, $X X X(1 \& 2)$, 8697.

Visitation Committee to Public Universities 2006. (2007). Report of the visitation committee to public universities. Kampala: Author.

Wakanyasi, N. (2002). Capacity utilization of information technology in organizations: A case study of Nkumba University. Unpublished Masters Thesis, Nkumba University.

Wild, P., \& Walker, J. (2001). The commercially developed SIMS from a humble beginning. In A. J. Visscher, P. Wild \& A. C. W. Fung (Eds.), Information technology in educational management: Synthesis of experience, research and future perspectives on computer-assisted school information systems (pp. 19-38). Dordrecht: Kluwer.

Zziwa, G. (2001). Computer utilization in the management of students' information at Makerere University. Unpublished Masters Thesis, Makerere University, Kampala. 